\title{
Teaching And Learning Writing Using Teacher's Written Feedback And Conference
}

\author{
lisrohli Irawati \\ STKIP PGRI Pacitan \\ Jl. Cut Nya' Dien $4^{\text {a }}$ Pacitan, East Java, Indonesia \\ iisrohlii@yahoo.com \\ Linda maharani \\ Kinderstation \\ Jl. Adisucipto Km.9 No. 9B, Maguwoharjo, Yogyakarta \\ lindamaharani550@rocketmail.com
}

\section{Abstract}

The objective of this study is to find out whether there is a significant difference in terms of writing skills improvements between the 8th grade students of SMP N 1 Prambanan Sleman who are given teacher's written feedback and conference and those who are not in the academic year of 2011/2012. This study involved 71 students from two groups, Class VIII B (35 students) as the experimental group and Class VIII A (36 students) as the control group. The experimental group was given teacher's written feedback and conference in the writing learning process, whereas the control group was given peer's feedback. The data were obtained by using two essay writing tests. They were administered to the two groups as the pre-test and post-test. The pre-test was given to both groups before the treatment was given and the post-test was given after the treatment finished. The data of the pre-test and post-test of both groups were analyzed by means of descriptive and inferential statistics. After the data were tested and found to be homogeneous and normal, the hypothesis was tested using the analysis of covariance (ANCOVA). The results show that there is a significant difference in the writing ability between the 
students who are given teacher's written feedback and conference and those who were not. It can be seen in the result of the hypothesis testing using ANCOVA. The significant value of 0.001 is less than the significance level of $0.05(0.001<0.05)$, which means that the data of this study are considered to have a significant difference. Therefore, the hypothesis of this study is accepted. It means that the technique of giving teacher's written feedback and conference significantly improves the students' writing ability in the English teaching and learning process in SMP N 1 Prambanan Sleman.

Keywords: Teaching and Learning Writing, Teacher's Feedback and Conference, Experimental Research

\section{Abstrak}

Tujuan penelitian ini adalah untuk mengetahui apakah ada perbedaan yang signifikan dalam perbaikan keterampilan menulis siswa kelas 8 SMP N 1 Prambanan Sleman yang diberi umpan balik secara tertulis oleh guru dan konferensi/tatap muka dan mereka yang tidak mengikuti pelajaran di tahun akademik 2011/2012.Penelitian ini melibatkan 71 siswa dari dua kelompok, kelas VIII B (terdiri dari 35 siswa) sebagai kelompok eksperimen dan kelas VIII A (36 siswa) sebagai kelompok kontrol. Kelompok eksperimen diberi umpan balik secara tertulis oleh guru dan konferensi/tatap muka dalam proses pembelajaran writing/menulis, sedangkan kelompok kontrol diberiumpan balik /feedback sesama pembelajar/peer. Data diperoleh dengan menggunakan dua Ujian menulis esai. Mereka dikelompokkan menjadi dua kelompok sebagai pre-test dan post-test. Pre-test diberikan kepada kedua kelompok sebelum tindakan dilaksanakan dan post-test diberikan setelah tindakan diselesaikan. Data dari pre-test dan post-test dari kedua kelompok dianalisis menggunakan statistik deskriptif dan inferensial.

Setelah data diuji dan ditemukan dalam keadaan homogen dan normal, hipotesis diuji dengan menggunakan analisis kovarian (ANCOVA). Hasil penelitian menunjukkan bahwa ada perbedaan yang signifikan dalam kemampuan menulis antara para siswa yang diberi umpan balik oleh guru secara tertulis dan konferensi/tatap muka dan dibandingkan dengan mereka yang tidak. Hal ini dapat dilihat pada hasil pengujian hipotesis menggunakan ANCOVA. Nilai yang signifikan 0,001 adalah kurang dari tingkat signifikansi $0,05(0,001<0,05)$, yang berarti bahwa data penelitian ini dianggap memiliki perbedaan yang signifikan. Oleh karena itu, 
hipotesis penelitian ini diterima. Ini berarti bahwa teknik memberikan umpan balik oleh guru secara tertulis dan konferensi/tatap muka secara signifikan mampu meningkatkan kemampuan writing/menulis siswa dalam pengajaran bahasa Inggris dan proses belajar di SMP N 1 Prambanan Sleman.

Kata Kunci: Pengajaran dan Pembelajaran, Umpan Balik Menulis oleh Guru dan Konferensi/Tatap Muka, Penelitian Eksperimental

\section{Introduction}

The Indonesian ministry of education recommends English as a subject tested in national exam (UNAS). English, then, is taught to children since they are in the kindergarten and elementary school. It can make the children familiar with English at an earlier age for their preparation to take the next formal education. It can also improve their awareness toward foreign languages.

The English teaching and learning process in Indonesian Junior High Schools (SMP) is aimed to enable the learners to reach the functional level, i.e. to communicate in both spoken and written form. In speaking, students have to be able to speak English fluently. On the other hand, in writing students are demanded to be able to understand and even to produce some short functional texts, such as procedure, descriptive, recount, narrative, and report, related to their daily life.

In studying English in junior high school, students have to acquire the four language skills: listening, speaking, reading, and writing. Listening and reading are receptive skills in which the students get an input of the language, while speaking and writing are productive skills in 
which the students produce the language as the result of the English learning process. Additionally, there is a different process to acquire speaking and writing in which the ability to write well is not naturally acquired. It is learned as a set of process by doing many practices as learning experience.

Based on the observation in SMPN (State Junior High School) 1 Prambanan, Sleman, there were some problems that inhibit the English teaching and learning process. English writing class did not run well. Most of the students showed a low ability during the writing activities reflected by the students' score in writing activity in which most of the students' score were under the minimum standard.

Many students thought that writing was difficult. They generally had a problem with English complex vocabularies. The complexities are related to the spelling and meaning; the spelling of some words can be different from the pronunciation. Even sometimes, a word has some different pronunciations. In addition, it is also difficult to remember the meaning of some words. The students stated that they got difficulty to remember the English vocabulary since they often found many unfamiliar words. Furthermore, English grammar became another problem. The differences between Indonesian and English grammar confused many students. The students often made some grammatical mistakes, such as tenses, part of speech, subject-verb agreement, etc. Finally, the students also had a problem to get idea to start writing. Even sometimes they took more than an hour just to think of the first sentence of their text. In fact, they often had many ideas in their mind, but it was difficult for them to express these ideas comprehensively.

Based on the above facts, it seems that students need teacher's 
control during this activity in form of feedback. Written feedback can be the best feedback given, including some correction symbols and comments, within which the students can revise them later. Unfortunately, there is a problem whether the students can understand the feedback or not. Hence, it is important to make sure that the students understand the feedback appropriately, so that they can correct their mistakes by themselves. Hence, to anticipate the students' confusion about the feedback, the teacher has to give an opportunity for the students to clarify the feedback in their writing paper by holding a conference in the writing class.

\section{Writing Skills}

Writing deals with some aspects which should be known by the learners. Writing is not only about theoretical idea, but it more concerns on practical thing. In facts, writing deals with some sub-skills, including micro- and macro- skills, and formation components including content, punctuation, spelling, and vocabulary. In order to acquire the writing skills, there are some micro and macro skills which should be mastered by the learners. Brown (2004:221) states that micro and macro skills include:

1. Produce graphemes and orthographic patterns of English.

2. Produce writing at an efficient rate of speed to suit the purpose.

3. Produce an acceptable core of words and use appropriate word order patterns.

4. Use acceptable grammatical systems (e.g., tense, agreement, pluralization), patterns, and rules.

5. Express a particular meaning in different grammatical forms. 
6. Use cohesive devices in written discourse.

7. Macroskills

8. Use the rhetorical forms and conventions of written discourse.

9. Appropriately accomplish the communicative functions of written texts according to form and purpose.

10. Convey links and connections between events, and communicate such relation as main idea, supporting idea, new information, given information, generalization, and exemplification.

11. Distinguish between literal and implied meanings when writing.

12. Correctly convey culturally specific references in the context of the written text.

13. Develop and use a battery of writing strategies, such as accurately assessing the audience's interpretation, using prewriting devices, writing with fluency in the first drafts, using paraphrases and synonyms, soliciting peer and instructor feedback, and using feedback for revising and editing.

For students, besides mastering those skills, they also have to regard to the mechanical components of writing. These include handwriting, spelling, punctuation, and the construction of well-formed sentences, paragraphs, and texts (Harmer: 2004). Gower, et al (1995) also agrees that writing involves many different aspects: handwriting, punctuation, spelling, sentence construction, organizing a text and paragraphing, text cohesion, and also register/style. The teacher should teach all of the aspects above as well as possible. Therefore, the teacher should be able to encourage their students by preparing them for writing skills above, such as giving a real writing task and a sufficient time which may raise the students' positive and co-operative attitude toward writing 
activity.

In line with opinion above, Richards and Renandya (2002) assert that writing consists of many constituent parts where the teacher needs to consider in which ones will be the most important for a course. Those constituents consist of content, organization, originality, style, fluency, and accuracy. Unfortunately, the teacher cannot teach these aspects all at once. Therefore, it is important for the teacher to make the priority which ones should be taught first based on students' needs.

In writing practice, there are some aspects that should be considered

related to the students written work, they are (1) content which consists of the factual information, interpretations, and ideas that a writer uses. It takes in main idea articulation, use of details, and completeness of communication about ideas and/or events being discussed in the writing (Bratcher and Ryan: 2004), (2) punctuation which determines the quality of written form. It is related to the use of capital letters, commas, full stops, question marks, etc., (3) spelling in which English spelling is complex but it is not completely random and is, in fact, fairly regular, there are usually clear rules about when certain spellings are and are not acceptable (Harmer: 2004), (4) the choice of vocabulary is very important in producing a written work. This skill is related to the choice of appropriate vocabulary. Some components above are important to be focused on at certain stage of learning to write in English by the students. By having the macro- and micro skills and also mastering the mechanical components above, students will be able to write in both grammatically and semantically acceptable. 


\section{Teaching writing in Junior High Schools}

Schools in Indonesia apply the School Based Curriculum or KTSP (Kurikulum Tingkat Satuan Pendidikan) as a reference to teach English. The aim of English teaching and learning process in Junior High School is to enable the learners to reach the functional level, i.e. to communicate in both spoken and written form. In relation to written communication, writing becomes the important skill to be mastered. Writing is an integral part in the curriculum. Therefore, the teaching and learning process of writing in Junior High School should be based on basic competencies and standard of competencies as stated in the standard of graduation.

In reference to the School Based Curriculum 2006, the expected writing competencies from second grade students of Junior High School in the first semester are presented in Table 1.

Table 1

English Writing Competences of Junior High Schools grade VIII of the First Semester

\begin{tabular}{|c|c|c|}
\hline $\begin{array}{c}\text { Standards of } \\
\text { Competencies }\end{array}$ & Basic Competencies & Indicators \\
\hline writing & - Revealing meaning & - Completing short \\
\hline Revealing meaning in & in functional written & functional texts. \\
\hline functional written text & text using a variety of & - Arranging words into \\
\hline and simple short & written language & meaningful \\
\hline essay in descriptive, & accurately, smoothly & functional texts \\
\hline and recount to & and appropriately to & - Writing short \\
\hline interact with & interact with their & functional texts \\
\hline
\end{tabular}




\begin{tabular}{|l|l|l|}
\hline surroundings & surroundings & - Completing short \\
- Revealing meaning & descriptive essay \\
and rhetoric steps in & texts \\
simple short essay & - Arranging sentences \\
using a variety of & into meaningful texts \\
written language & in form of \\
accurately, smoothly & descriptive/recount \\
and appropriately to & - Writing Essay in \\
interact with & form of descriptive \\
& environment in the & /recount \\
& form of descriptive & \\
& text & \\
& and recount & \\
& & \\
\hline
\end{tabular}

The teaching writing in Junior High School concerns on some texts, while in the first semester of 8th grade, the students have to deal with descriptive and recount texts. They are expected to be able to deal with those texts related to their daily life accurately and fluently. Besides, the teaching of writing in Junior High School should be done appropriately. Students of Junior high school are in the age of 12 to 14 years old and categorized as adolescent. The teacher should know the characteristic of the students and use an appropriate approach. As Dorn and Soffos (2001) say that in teaching writing to young learners, teachers have to recognize the complexity of the process and also think a moment about what happens in the mind of their students as they create a written work. 


\section{Research Method}

This research used a quasi-experimental study. In this study, there were two variables. The first variable was the independent variable or the treatment of the research. In this study, the treatment used was the combination of teacher's written feedback and conference. The second variable was the dependent variable or the students' writing skills. The population of the study was the 8th grade students of SMP N 1 Prambanan in the academic year of 2011/2012. There were three classes of the $8^{\text {th }}$ grade in the school and the researcher selected two of them as the sample of the research, one as the experimental group and the rest as the control group.

\section{Discussion}

The data description explains the results of the tests. As mentioned earlier, there were two kinds of tests in this research. They were pre-test and post-test. In this research, the researcher used essay writing tests to examine the students' writing skills. Below are the results of those tests.

\section{Pre-test}

The data of the pre-test Scores on writing skills of the control class

Based on the result of the calculation, it shows that the gained mean score of the control class in the pre-test is 62.29 , meanwhile the SD of the score is 2.96 . 
Table 2

Descriptive Analysis of the Control Class in the Pre-test

\begin{tabular}{|l|l|l|l|l|}
\hline \multicolumn{1}{|c|}{$\mathbf{N}$} & \multicolumn{1}{c|}{ Mean } & \multicolumn{1}{c|}{ SD } & \multicolumn{1}{c|}{ Minimum } & Maximum \\
\hline 36 & 62.29 & 2.96 & 58.00 & 69.00 \\
\hline
\end{tabular}

The data of the pre-test Scores on writing skills of the experimental Class Based on the result of the calculation, it shows that the gained mean score of the experimental class in the pre-test is 62.17 , meanwhile the SD of the score is 2.79 . The maximum score gained in the test is 69.00 and the minimum score is 58.00 . Table 3 shows the descriptive analysis of the experimental class in the pretest.

Table 3

Descriptive Analysis of the Experimental Class in the Pre-test

\begin{tabular}{|l|l|l|l|l|}
\hline $\mathbf{N}$ & Mean & SD & Minimum & Maximum \\
\hline 35 & 62.17 & 2.79 & 58.00 & 69.00 \\
\hline
\end{tabular}

The comparison of the pre-test scores on writing skills between the control and experimental classes

The result of the pre-test scores of both classes is compared to find out the difference of students' writing skills of both classes before the treatment is conducted. Table 4 displays the statistical data showing the comparison between the pre-test scores on writing skills of the control and experimental classes.

Table 4

The Comparison of the Pre-test Scores on Writing Skills between the Control and Experimental Classes

\begin{tabular}{|l|l|l|l|}
\hline Data & N & M & SD \\
\hline $\begin{array}{l}\text { Pre-Test Scores on } \\
\begin{array}{l}\text { Writing Skills of } \\
\text { the Control Class }\end{array}\end{array}$ & 36 & 62.29 & 2.96 \\
\hline
\end{tabular}




\begin{tabular}{|c|c|c|c|}
\hline $\begin{array}{l}\text { Pre-Test Scores on } \\
\text { Writing Skills of } \\
\text { the Experimental } \\
\text { Class }\end{array}$ & 35 & 62.17 & 2.79 \\
\hline
\end{tabular}

The data of the pre-test on writing skills of the control class show that the mean score is (62.29) and the standard deviation is (2.96). Meanwhile, the data of the pre-test on writing skills of the experimental class show that the mean score is (62.17) and the standard deviation is (2.79). It can be seen from the table that the mean scores of the pre-test on writing skills of the control and experimental classes are different. The mean score of the pre-test of the control class is a little bit higher than that of the experimental one.

Post- test

The data of the post-test scores on writing skills of the control class

Based on the result of the calculation, it shows that the gained mean score of the control class in the post-test is 68.29 , meanwhile the $\mathrm{SD}$ of the score is 2.50 . The maximum score gained in the test is 73.00 and the minimum score is 64.00 . The result of the statistical data can be seen in Table 5.

Table 5

Descriptive Analysis of the Control Class in the Post-test

\begin{tabular}{|l|l|l|l|l|}
\hline $\mathbf{N}$ & Mean & SD & Minimum & Maximum \\
\hline $\mathbf{3 6 . 6 8}$ & 29 & $\mathbf{2 . 5 0}$ & $\mathbf{6 4 . 0 0}$ & $\mathbf{7 3 . 0 0}$ \\
\hline
\end{tabular}

The data of the post-test scores on writing skills of the experimental class Based on the result of the calculation, it shows that the gained mean score of the experimental class in the post-test is 70.07, meanwhile the SD of the score is 2.51 . The maximum score gained in the test is 
75.00 and the minimum score is 65.00 . The statistical data can be seen in Table 6.

Table 6

Descriptive Analysis of the Experimental Class in the Post-test

\begin{tabular}{|l|l|l|l|l|}
\hline $\mathbf{N}$ & Mean & SD & Minimum & Maximum \\
\hline 35 & $\mathbf{7 0 . 0 7}$ & $\mathbf{2 . 5 1}$ & $\mathbf{6 5 . 0 0}$ & $\mathbf{7 5 . 0 0}$ \\
\hline
\end{tabular}

The comparison of the post-test scores on writing skills between the control and experimental classes

The result of the post-test scores of both classes is compared to find out the difference of student's writing skills of both classes after the treatment is conducted. Table 8 displays the statistical data showing the comparison between the post-test scores on writing skills of the control and experimental classes.

Table 8

The Comparison of the Post-test Scores on Writing Skills between Control and Experimental Classes

\begin{tabular}{|l|l|l|l|}
\hline Data & N & M & SD \\
\hline $\begin{array}{l}\text { Post-Test Scores on } \\
\text { Writing Skills of the } \\
\text { Control Class }\end{array}$ & 36 & 68.29 & 2.50 \\
\hline $\begin{array}{l}\text { Post-Test Scores on } \\
\text { Writing Skills of the } \\
\text { Experimental Class }\end{array}$ & $\mathbf{3 5}$ & $\mathbf{7 0 . 0 7}$ & $\mathbf{2 . 5 1}$ \\
\hline
\end{tabular}

The data of the post-test on writing skills of the control class show that the mean score is (68.29) and the standard deviation is (2.50). Meanwhile, the data of the post-test on writing skills of the experimental class show that the mean score is (70.07) and the standard deviation is (2.51). It can be seen from the Table 8 that the mean score of the post-test of the experimental class is higher than that of the Control Class. 


\section{Inferential analysis}

The inferential analysis describes pre-testing analysis and hypothesis testing as presented below.

Pre-testing analysis

Before the hypothesis testing was applied, pre-testing analysis was done first. Pre-testing analysis consisted of two tests, including the normality and homogeneity tests. The normality test was employed to test whether the data of the scores show the normal distribution, and the homogeneity test was used to test whether the sample's variance is homogeneous or not. The results are presented as follows.

Normality test

The test of normality is aimed at finding out whether the data of the scores show a normal distribution. In this case, the KolmogorovSmirnov test was employed. Theoretically, if the value of $\mathrm{p}$ is greater than 0.05 , the data are said to be normal. If it is below 0.05 , the data significantly deviate from a normal distribution. Table 9 presents the result of the normality test of students' pre-test and post-test.

Table 9

The Result of the Normality Test of the Students' Writing Skills Variables $p$ value $\alpha$ Statement

\begin{tabular}{|l|l|l|l|}
\hline Variables & p value & A & Statement \\
\hline $\begin{array}{l}\text { Pre Test of } \\
\text { Control Class }\end{array}$ & 0.652 & 0.05 & Normal \\
\hline $\begin{array}{l}\text { Pre Test of } \\
\text { Experimental } \\
\text { Class }\end{array}$ & 0.732 & 0.05 & Normal \\
\hline $\begin{array}{l}\text { Pre Test of } \\
\text { Control Class }\end{array}$ & 0.768 & 0.05 & Normal \\
\hline Pre Test of & 0.779 & 0.05 & Normal \\
\hline
\end{tabular}


Experimental

Class

Table 9 displays the normality of pre-test and post-test of both classes.The result of normality for the pre-test of control and experimental classes are (0.652) and (0.732) in a row. Meanwhile, the result of normality for the post-test of control and experimental classes are $(0.768)$ and $(0.779)$ in a row. Since all these $p$ value are greater than 0.05 , it can be said that all of the data have a normal distribution.

\section{Homogeneity test}

The homogeneity test is used to find out whether the sample variance is homogeneous or not. In this case, the Levene-Test was employed on the data of pre-test and post-test. The relationship can be considered homogeneous if the significant value is higher than significance level of 0.05 . The homogeneity test was done in writing skills before and after the treatment (pre-test and post-test).

Table 10

The Result of the Homogeneity Test of the Pre-Test and Post-Test of the Control and Experimental Classes Variable df1 df2 Sig. Statement

\begin{tabular}{|l|l|l|l|l|}
\hline Variable & df1 & df2 & Sig. & Statement \\
\hline Pre-test & 1 & 69 & 0.920 & homogenous \\
\hline Post-test & 1 & 69 & 0.936 & homogenous \\
\hline
\end{tabular}

From the table above, it indicates that the $\mathrm{p}$ value is higher than the significance level of $5 \%$ or 0.05 for both pre-test and post-test sections, i.e. $\mathrm{p}$ value $(0.920)>\boldsymbol{\alpha}(0.05)$ for the pre-test and $\mathrm{p}$ value $(0.936)>\boldsymbol{\alpha}$ (0.05) for the post-test. Thereby, it can be stated that the sample variance 
in the pre-test and post-test is homogeneous.

\section{Hypothesis testing}

The researcher then did an analysis to test the hypothesis of the study. The hypothesis testing is aimed at revealing whether the students who are given teacher's written feedback and conference on their writing class will have better writing skills than the students who are not. Firstly, the hypothesis must be changed to the null hypothesis (Ho) before the hypothesis is rejected or accepted. Muijs (2004) says that the alternative hypothesis is the one that the researcher wants to be true, while the null hypothesis is the opposite. The hypothesis testing between experimental and control groups can be seen from the following explanation:

a. Null Hypothesis (Ho): The students who are given teacher's written feedback and conference on their writing class will not have better writing skills than the students who are not.

b. Alternative Hypothesis (Ha): The students who are given teacher's written feedback and conference on their writing class will have better writing skills than the students who are not.

In this research, the researcher analyzed the hypothesis and the data by using SPSS 16.00 computer program for windows. In testing the hypothesis, ANCOVA (Analysis of Covariance) was used since this research involved the scores of both the pre-test and post-test and the mean scores of the pre-test of both classes were different.

In hypothesis testing, if the value of the level of significance is lower than 0.05 , the hypothesis is theoretically accepted. The result of the ANCOVA test is presented in Table 11. 
Table 11

The Result of ANCOVA

\begin{tabular}{|l|l|l|l|l|l|}
\hline Source & $\begin{array}{l}\text { Type III } \\
\text { Sum of } \\
\text { square }\end{array}$ & $\mathbf{d t f}$ & $\begin{array}{l}\text { Mean Square } \\
\text { F Sig }\end{array}$ & F & Sig \\
\hline $\begin{array}{l}\text { Corrected } \\
\text { Model }\end{array}$ & $136.307 \mathrm{a}$ & $\mathbf{2}$ & $\mathbf{6 8 . 1 4 5}$ & $\mathbf{1 3 . 0 6 7}$ & $\mathbf{. 0 0 0}$ \\
Intercept & 311.399 & $\mathbf{1}$ & $\mathbf{3 1 1 . 3 9 9}$ & $\mathbf{5 9 . 7 6 5}$ & $\mathbf{. 0 0 0}$ \\
PRETEST & & $\mathbf{1}$ & $\mathbf{8 0 . 0 9 5}$ & $\mathbf{1 5 . 3 5 7}$ & $\mathbf{. 0 0 0}$ \\
group & & $\mathbf{1}$ & $\mathbf{5 9 . 0 6 2}$ & $\mathbf{1 1 . 3 2 4}$ & $\mathbf{. 0 0 1}$ \\
Error & & $\mathbf{6 8}$ & $\mathbf{5 . 2 1 6}$ & & \\
Total & & $\mathbf{7 1}$ & & & \\
$\begin{array}{l}\text { Corrected } \\
\text { Total }\end{array}$ & & $\mathbf{7 0}$ & & & \\
\hline
\end{tabular}

Regarding to the result shown in Table 16, it can be identified that the level of significance is 0.001 . Since the level of significance value is less than 0.05 , i.e. $0.001<0.05$, the null hypothesis $(\mathrm{Ho})$ is rejected. It means that the use of teacher's written feedback and conference shows a significant difference on students' writing skills seen from the result of the pos-test. In other words, it also states that the use of teacher's written feedback and conference has an influence to the student's writing skills. Therefore, the hypothesis of "The students who are given teacher's written feedback and conference on their writing class will have better writing skills than the students who are not" is accepted. 


\section{Interpretation}

In this part, the interpretation of the findings is presented. The interpretation is concerned with the descriptive and inferential interpretations. Based on the descriptive analysis, it is found that the mean scores of the post-test of both classes are higher than that of the pre-test. It means that both control and experimental classes have an improvement of the mean score on students' writing skills. The improvement of the mean score in control class is (6.00). Meanwhile, the improvement of the mean score in experimental class is (7.90). In brief, it seems that the improvement of the mean score in experimental class is higher than that of the control class. The improvement of the mean score of writing tests of the control and experimental classes is presented in Table12

Table 12

The Improvement of the Mean Score of Writing Tests of the Control and Experimental Classes Variable Mean The improvement

\begin{tabular}{|c|c|c|c|}
\hline Variable & & Mean & Improvement \\
\hline Control & Pre-test & 62.29 & 6.00 \\
\hline & Post-test & 68.29 & \\
\hline Experiment & Pre-test & 62.17 & 7.900 \\
\hline & Post-test & 70.07 & \\
\hline
\end{tabular}

Then, the inferential analysis resulted that all of the data have a normal distribution and find to be homogeneous. Based on the hypothesis testing, it is found that the students who were given teacher's written feedback and conference on their writing class had better writing skills than the students who were not. From the ANCOVA result, it can be seen that the value of the level of significance is lower than 0.05 , i.e. $0.001<$ 0.05 , which means that there is a significance difference in the post-test 
scores between the two groups after controlling the pre-test scores as the covariate. Besides, the significant difference also can be seen from the adjusted means of both classes as presented in Table 13 .

Table 13

Summary Means

\begin{tabular}{|c|c|c|c|}
\hline Variabel & N & Post-test & Adjusted Mean \\
\hline $\begin{array}{c}\text { Experimental } \\
\text { Class }\end{array}$ & $\mathbf{3 5}$ & $\mathbf{7 0 . 0 7}$ & $\mathbf{7 0 . 0 9}$ \\
\hline Control Class & $\mathbf{3 6}$ & $\mathbf{6 8 . 2 9}$ & $\mathbf{6 8 . 2 7}$ \\
\hline
\end{tabular}

Table 13 shows that the mean score of the post-test achieved by the experimental class which was taught using teacher's written feedback and conference is higher than the mean score of the control class (i.e. 70.07 > 68.29). Then, because the means of the covariate or the pre-test were not exactly the same for the two classes, the means of the dependent variable or the post-test had to be adjusted. The adjusted mean of the experimental class is also higher than that of the control class (i.e. 70.09 > 68.27). Briefly, the means score of the experimental class are always higher than that of the control class whether it is adjusted for differences in the covariate or not. In other words, it states that the use of teacher's written feedback and conference has a positive influence on the student's writing skills. Thus, the hypothesis proposed in this research is accepted.

\section{Finding}

In this study, the pre-test and post-test have been administered to both experimental and control classes to find out the students' writing 
skills before and after the treatment. The data of pre-test and post-test were gathered from writing test of descriptive and recount texts. Then, the treatment of teacher's written feedback and conference were only given to the experimental class. Therefore, the effect of teacher's written feedback and conference on students' writing skills can be identified through the result of ANCOVA.

The findings of the research proved that there was a significant difference between the writing skills of the students who were taught using teacher's written feedback and conference and those who were not. These findings support the theories about the contribution of teacher's written feedback and conference to students' writing skills. It has been discussed in Chapter II that teacher's written feedback andconference separately bring many advantages to students' writing activities. As Askew (2000) says that teacher's feedback provides information to help the students learn. Feedback is given in the belief that the recipient will be able to revise their work to be better.

Unfortunately, a study conducted by Sommers in 1982 reveals that too much written feedback, without a conference, is poor of quality and frequently misunderstood by the students. It may be difficult for students to understand or interpret the feedback which contains comments, correction symbols, etc, without a clear explanation. Consequently, students cannot do anything with this feedback. If students fail to understand the feedback that they get, they may ignore or delete them from their revised draft (Hyland: 2003). Supporting the result of the study above, Marzano and Arthur in Ferris (2003) say that teacher's written commentary on student's writing might just end in failure. They concluded three implications of previous research on the effects of 
teacher commentary. They say that: “(1) students often do not comprehend teacher responses to their writing; (2) even when they do, they do not always use those responses and may not know how to use them; (3) when they use them, they do not necessarily write more effectively as a result." Therefore, a conference can be done to avoid the misunderstanding between the students and the teacher about the written feedback. As Kroll in Richards and Renandya (2002) says that conferencing allows the teacher to uncover potential misunderstanding that the students might have about the writtenfeedback. It can be a good alternative way to accompany teacher's written feedback on students' writing, as Brender and Fregeau in Williams (2003) say that written feedback will be more effective when it is coupled with students-teacher conferencing.

From the explanation above, it can be concluded that giving teacher's written feedback and conference is appropriate to be employed as a good combination technique in teaching writing for the level of Junior High School. The students in this level still need teacher's intervention in the learning process considering that they are categorized as adolescent and seems to be dependent learners.

In addition, the benefit of teacher's written feedback and conference can be seen from the students' scores. The result of post-test of the experimental class, in which the students were given teacher's written feedback and conference, shows that the mean score is higher than that of the control class, in which thestudents were not given teacher's written feedback and conference, i.e. $70.07>68.29$. Moreover, the result of ANCOVA test shows that the value of significance is lower than 0.05 , i.e. $0.001<0.05$. It means that there is a significant difference 
on students' writing skills who were given teacher's written feedback and conference and those who were not. Finally, the hypothesis proposed in this research which says "The students who are given teacher's written feedback and conference on their writing class will have better writing skills than the students who are not" is accepted.

\section{Conclusions}

This study investigated the effects of teacher's written feedback and conference on VIIIth grade students' writing skills of SMP N 1 Prambanan Sleman. The feedback used in this research included comments and correction symbols that came from the teacher. Meanwhile, the conference was held to clarify the teacher's written feedback. Then, the result of the research indicated that the use of teacher's written feedback and conference could improve the students' writing skills. This result supports some theories stated by some other researchers which suggest that the use of teacher's written feedback and conference is effective for writing activities in class.

In line with the research finding and the discussion in the previous chapter, the researcher proposed some conclusions, they are:

First, the technique of giving teacher's feedback is good to be applied to the students in the Junior High School level considering that they still need the teacher's intervention in the learning process of writing. Then, the feedback is good to be given in the correction symbols so that they can correct the mistakes by themselves. Besides, the feedback is good to be given in the written form so that the students can review them later. On the other hand, it also has a negative side. Many students do not understand the meaning of teacher's written feedback 
appropriately.

Second, conference can be a good alternative way to accompany the teacher's written feedback in order to avoid the misunderstanding between the students and the teacher. Finally, the students will understand their mistakes appropriately so that they can correct the mistakes by themselves. Therefore, it is possible that giving teacher's written feedback and holding a conference will improve the students' writing skills.

Third,the combination of teacher's written feedback and conference is effective to be applied to the VIIIth grade students in SMP N 1 Prambanan Sleman in the Academic Year of 2011/2012 of the first semester.

\section{References}

Askew, S. 2000. Feedback for Learning. London: Routledge Falmer.

Berne, J. 2009. The Writing- Rich Highschools Classrom. New York: The Guildford Press.

Bratcher, S. and Ryan, L. 2004. Evaluating children's writing. New Jersey: Lawrence Erlbaum Associates.

Brown, H.D. 2001. Teaching by Principles. New York: Pearson Education.

2004. Language Assessment: Principles and Classroom Practices. New York: Pearson Education.

Cohen, L., Manion, L., Morrison, K. 2005. Research Methods in Education: 5th Edition. New York: RoutledgeFalmer.

Cox, S. and Kooser,T. 2006. Writing Brave and Free. Chicago: University of Nebraska.

Creswell, J. W. 2008. Educational Research: Planning, Conducting, and Evaluating Quantitative and Qualitative Research. New Jersey: Pearson Education.

Dorn, L. J. and Soffos, C. 2001. Scaffolding Young Writers. Maine: Stenhouse Publisher. 
Ferris, D. 2003. Response to Student Writing. New Jersey: Lawrence Erlbaum Associates.

Fraenkel, J.R. and Wallen, N. E. 2006. How to Design and Evaluate Research in Education, sixth edition. New York: McGraw Hill.

Fulcher, Glenn and Davidson, Fred. 2007. Language Testing and Assessment. Oxon: Routledge.

Gower, R. Philips, D. Walters, S. 1995. Teaching Practice: A handbook for teachers in training. Oxford: Macmillan.

Harmer, Jeremy. 2001. The Practice of English Language Teaching: Third Edition. Cambridge: Longman. 2004. How to Teach Writing. Harlow: Pearson Education Ltd.

Hughes, A. 2003. Testing for Language Teachers. Cambridge: Cambridge University Press.

Hyland, K. 2003. Second Language Writing. Cambridge: Cambridge University Press.

Lawrence, W.N. 2007. Basics of Social Research: Qualitative and Quantitative Approaches. Whitewater: Pearson Education.

Linse,C.T. 2005. Practical English Language Teching:Young Learners. New York: McGraw-Hill Company.

Magno,C. and Amarles, A. M. 2011. "Teachers' Feedback Practices in Second Language Academic Writing Classrooms". The International Journal of Educational and Psychological Assessment, Vol. 6(2), P.28.

Muijs, D. 2004. Doing Quantitative Research in Education with SPSS. London: Sage Publications.

Nation, I.S.P. 2009. Teaching ESL/EFL Reading and Writing. New York: Routledge.

Reid, J. M. 1993. Teaching ESL Writing. University of Wyoming : Prentice Hall Regents.

Richards, J. and Renandya,W. 2002. Methodology in Language Teaching. Cambridge: Cambridge University Press.

Rijlaarsdam, G. 2005. Effective Learning and Teaching of Writing. Boston: Kluwer Academic Publishers.

Rooks, G.M. 1999. Paragraph Power: Communicating Ideas Through Paragraph. New York: Pearson Education.

Singh, Y. K. 2006. Fundamental of Research Methodology and Statistics. New Delhi: New Age International.

Stemler, Steven E. 2004. A comparison of consensus, consistency, and measurement approaches to estimating interrater reliability. 
Practical Assessment, Research \& Evaluation, 9(4). retrieved onMay $21^{\text {st }} 2011$ from http://PAREonline.net/getvn.asp? $v=9 \& n=4$. Sugiyono. 2008. Statistika Untuk Penelitian. Bandung: Alfabeta.

Urquhart,V. and McIver,M. 2005. Teaching Writing in the Content Areas. Virginia: ASCD

Weigle, S.C. 2002. Assessing Writing. Cambridge: Cambridge University Press.

Williams, G, Jason. 2003. 'Providing Feedback on ESL Students' Written Assignment”. The Internet TESL Journal, Vol. IX, No.10. 